\title{
Design of Artificial Neural Networks to Recognize Fingerprint Patterns
}

\author{
${ }^{1}$ Frinto Tambunan, ${ }^{2}$ Yudi $Y,{ }^{3}$ Muhammad Fauzi \\ ${ }^{1,2,3}$ Universitas Potensi Utama, Medan, North Sumatra, Indonesia \\ frintoaja@gmail.com,yudisifo@gmail.com,mfauzixx@gmail.com
}

\begin{abstract}
Image or pattern recognition system is one of the branches in computer science, this system can help the processing of fingerprint patterns, especially in the banking, police and users of other institutions who really feel the importance of using fingerprints. Several stages in fingerprint pattern image recognition are through the process of scanning, then the resulting digital fingerprint image is converted to a certain value, among others, the threshold process, the division of images, and representation of input values. The training process is carried out using two treatments: the first with a different level of understanding and the second training with different unit numbers, the best training is obtained with a level of understanding of 0.3 and the number of hidden units 10 by producing a short training time and relatively small errors. Fingerprint pattern recognition is done by two trials, based on 1 number of training patterns and 5 number of training patterns. From the research data, the ability of the system to recognize output patterns is greater if the number of training patterns increases, with a number of 1 training patterns, the system is able to recognize 50\% external patterns while the 5 system training patterns are able to recognize $70 \%$ output patterns.
\end{abstract}

Keywords: Artificial Neural Networks, fingerprints, scanning, training, recognition.

\section{Introduction}

Currently the use of image technology to facilitate humans in solving certain problems has been widely applied, especially in the field of identification. Identification is an important process in recognizing and differentiating characteristics possessed by an object. One example is the self-recognition system which is a technology used to identify a person's identity through biometric identification techniques [1]. Biometric identification techniques are based on natural human characteristics, namely behavioral and physiological characteristics, biometric identification has advantages over conventional methods because it is not easily stolen or used by unauthorized users [2]. Physiological characteristics include iris patterns, retinal patterns, facial features and fingerprint patterns, while behavioral characteristics consist of fingerprint patterns [2] [3]. Humans can easily recognize a person's face, as well as one's voice even when talking on the telephone, the ease with which humans use to use interconnected elements in a network called neurons. Neurons to process the information obtained, whereas if a problem with the computer, will cause various difficulties [4] - [5].

In order for the computer to recognize images, the physical data needed is the form of images and other data such as adding textures and colors so that the computer will easily recognize it, but by using existing methods in artificial neural networks [6]. One of the most common and reliable types of ANN is backpropagation ANN. This method is a method approaching the output value with a comparison value. Many applications can be implemented using ANN with the reverse propagation method, one of which is fingerprint recognition. Fingerprint recognition is included in the pattern recognition problem, generally fingerprint recognition aims to identify someone who is part of a security system. Currently fingerprint identification is still done manually by matching the original 
fingerprint. Fingerprint recognition is a difficult problem in pattern recognition, because everyone's fingerprints have identical but not the same features. With different unique features, everyone can use it to identify them. In this case we need a software system to analyze and identify someone's fingerprint.

\section{Research Methodology}

\subsection{Image Acquisition}

The image acquisition process is the process of capturing fingerprint image data. The fingerprint image used is generated from the scanning process (Scanning).

\subsection{Image Segmentation}

The image segmentation process is an advanced image process that must be performed on fingerprint image data. Data processing is performed for each digital fingerprint image produced in the scanning process. Next is the mining (threshold), the mining process functions to change the color or RGB image into a black and white binary image [7]. The equation used in the process threshold.

$$
g(x, y)=\left\{\begin{array}{l}
1 \text { if } f(x, y) \geq T \\
0 \text { if } f(x, y)<T
\end{array}\right\} \cdots-1
$$

The resulting binary image then goes through a limit detection process to crop the image from the fingerprint pattern according to the size of the fingerprint pattern and discard the sides of the image that are not used.

\subsection{Feature extraction}

The feature extraction process is an advanced process of the image segmentation process, this process is carried out by dividing the image into 32 parts, and so on making a representational value input from each part image that will be used in the training process as a test well.

\subsection{ANN Training}

The propagation feedback algorithm was first formulated by Werbos and popularized by Rumelhart with McClelland for use on ANN. This algorithm includes training methods that are supervised and designed for operation on multi-layered feed backs [8]. Propagation training in research is carried out in several phases namely forward phase, reverse phase and weight change. In the advanced phase input signal xi together with initial weights and biases (vj, i) multiplied the screen is hidden with a binary sigmoid activation function so as to produce zj output from each hidden display unit. The equation used is:

$$
\underline{Z i n j}=V_{j 0}+X i \underline{V j i}(2) Z i \quad \ldots . .2
$$

The output is then returned to multiply forward with the activation function set to the output and produce a network output, the equation used is:

$$
\begin{aligned}
& \operatorname{yin}_{\mathrm{k}}=\mathrm{W}_{\mathrm{k} 0}+\sum_{j=1}^{p} \quad \mathrm{Z}_{\mathrm{j}} \mathrm{W}_{\mathrm{kj}} \\
& \mathrm{y}_{\mathrm{k}}=f\left(\operatorname{yin}_{k}\right)=\frac{1}{1+e^{-y n_{k}}}
\end{aligned}
$$

In the reverse phase of the calculation the error factor $(\delta)$ is calculated based on the error rate or the difference between the target output to the network output and calculates the value of the weight level change. The equation used is: 


$$
\begin{aligned}
& \delta_{k}=\left(t_{k}-y_{k}\right) f\left(y_{i n}\right) \\
& \Delta W_{j k}=\alpha \delta_{k} Z_{j} \\
& \delta i_{j}=\sum_{k=1}^{m} \quad \delta_{k} W_{k j}
\end{aligned}
$$

$$
\delta_{\mathrm{j}}=\sin _{\mathrm{j}} f\left(\mathrm{Zin}_{\mathrm{j}}\right)
$$

$$
\Delta \mathrm{V}_{\mathrm{ji}}=\alpha \delta_{\mathrm{j}} \mathrm{X}_{\mathrm{i}}
$$

The last phase is the weight change phase, the weight change is calculated based on the weight of the initial analysis results and the weight change weight is calculated by a factor. Network error on screen [4] - [7]. The equation used is:

$$
\begin{aligned}
& \mathrm{W}_{j \mathrm{k}}\left(\text { New) }=\mathrm{W}_{j \mathrm{k}} \text { (Old) }+\Delta \mathrm{W}_{j \mathrm{k}}\right. \\
& \mathrm{V}_{\mathrm{ji}} \text { (New) }=\mathrm{V}_{\mathrm{ji}} \text { (Old) }+\Delta \mathrm{V}_{j \mathrm{i}}
\end{aligned}
$$

The training process in the study was carried out with the first two improvements with different levels of understanding and the second with a number of different display units.

\section{a) Test the ANN}

The testing process in the study was conducted with two different experiments, the first test was carried out on a system with 1 number of training patterns and 10 test patterns as output data, the second test was carried out with a system with 5 number of training patterns and 10 number of test patterns as output data.

\section{b) Pattern recognition}

This process is the result of testing the ANN system, this process is performed by displaying the original fingerprint pattern image stored in the database if the system is able to recognize the input being tested.

\section{Results and Discussion}

The results of training tests with different levels of understanding are shown in Table 1 and a graph of the relationship between levels of understanding at length of study time is shown in Figure 1.

Table 1. Training Tables with different learning rates

\begin{tabular}{cccc}
\hline $\begin{array}{c}\text { Unit } \\
\text { Hidden } \\
\text { Laver }\end{array}$ & Error & $\begin{array}{c}\text { Duration } \\
\text { Of Training } \\
\text { (Seconds) }\end{array}$ & $\alpha$ \\
\hline 5 & 0.0000000059 & 9 & 0.3 \\
10 & 0.0000000013 & 14 & 0.3 \\
15 & 0.0000000095 & 20 & 0.3 \\
20 & 0.0000000156 & 27 & 0.3 \\
25 & 0.0000000073 & 15 & 0.3 \\
\hline
\end{tabular}




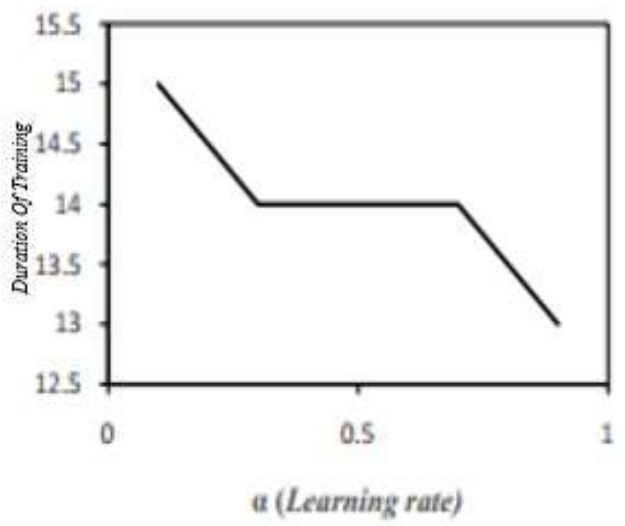

Figure 1. Relationship of learning rate with duration of training

The smaller number of hidden unit units will result in shorter learning time, but from the graph it appears when on the number of hidden screen units 25 , the duration of the retraining decreases to 15 seconds. The process of introducing an artificial neural network system to see the success of the system in recognizing fingerprint images that have been trained previously. Fingerprint images are used as learning data and new fingerprint patterns. In the process of testing the input image that will be tested will go through data processing automatically by the system, so that a direct representation of the fingerprint pattern image can be taken through the input. With the image data representation of the input image pattern to be tested, the system will match the representation of the fingerprint data on the pattern to be tested.

The success of testing 10 patterns. The output has a percentage of $80 \%$, the program is able to recognize most of the images from the tested patterns shown in Table 2.

Table 2. Relationship between the level of training patterns and the level of testing patterns

\begin{tabular}{|c|c|}
\hline $\begin{array}{c}\text { Level } \\
\text { Success } \\
\text { training pattern }\end{array}$ & $\begin{array}{c}\text { Level } \\
\text { Success } \\
\text { testing pattern }\end{array}$ \\
\hline$\sum \frac{3}{5} \times 1009$ & $\sum_{=7096} \frac{7}{10} \times 10096$ \\
\hline$\sum_{=100 \%} \frac{5}{5} \times 100 \%$ & $\sum_{=70 \%} \frac{7}{10} \times 10096$ \\
\hline$\sum \frac{5}{5} \times 10096$ & $\sum_{=70 \%} \frac{7}{10} \times 10096$ \\
\hline$\sum_{=100 \%} \frac{5}{5} \times 10096$ & $\sum_{-70 \%} \frac{7}{10} \times 10096$ \\
\hline$\sum_{=8096} \frac{4}{5} \times 10096$ & $\sum_{=7096} \frac{7}{10} \times 10096$ \\
\hline$\sum \frac{5}{5} \times 100 \%$ & $\sum_{=70 \%} \frac{7}{10} \times 10096$ \\
\hline$\sum_{=8096} \frac{4}{5} \times 100 \%$ & $\sum_{=9096} \frac{9}{10} \times 10006$ \\
\hline$\sum_{=8096} \frac{4}{5} \times 10096$ & $\sum_{=7096} \frac{7}{10} \times 10096$ \\
\hline$\sum \frac{5}{5} \times 100 \%$ & $\sum_{=60 \%} \frac{6}{10} \times 10096$ \\
\hline$\sum_{=100 \%} \frac{5}{5} \times 100 \%$ & $\sum_{=60 \%} \frac{6}{10} \times 10096$ \\
\hline
\end{tabular}

Pattern recognition is performed on 10 external fingerprint images using 5 number training patterns. From the data it can be seen that the same as in the testing process with 1 training pattern, testing with 5 training patterns still has a large percentage in the test pattern which is also used in the training process that is equal to $91 \%$ while in the testing 
process the test image pattern outside the pattern used in the training process has a fairly large percentage of success that is $70 \%$.

Table 3. System introduction data on output patterns with 5 training patterns

\begin{tabular}{|c|c|}
\hline $\begin{array}{c}\text { Tingkat } \\
\text { Keberhasilan } \\
\text { Pota } \\
\text { Pelatihaa } \\
\end{array}$ & $\begin{array}{c}\text { Tinglkat } \\
\text { Keberhasilan } \\
\text { Pola } \\
\text { Pentuilan }\end{array}$ \\
\hline $81 \%$ & $\sum_{-0 \%} \frac{0}{10} \times 100 \%$ \\
\hline $99 \%$ & $\sum_{=80 \%} \frac{B}{10} * 1006$ \\
\hline $99 \%$ & $\sum_{-10 \%} \frac{1}{10} \times 100 \%$ \\
\hline $99 \%$ & $\sum_{=70 \%} \frac{7}{10} \times 100 \%$ \\
\hline $99 \%$ & $\sum_{=70 \%} \frac{7}{10} \approx 100 \%$ \\
\hline $99 \%$ & $\sum \frac{4}{10} x \cdot 100 \%$ \\
\hline $99 \%$ & $\sum_{m 20 \%} \frac{2}{10} \approx 100 \%$ \\
\hline $99 \%$ & $\sum_{=70 \%} \frac{4}{10} \pi 100 \%$ \\
\hline $99 \%$ & $\sum_{-80 \%} \frac{8}{10} x .100 \%$ \\
\hline $99 \%$ & $\sum_{=50 \%} \frac{5}{10} \times 100 \%$ \\
\hline
\end{tabular}

The fingerprint pattern recognition system is a system that can be designed to recognize fingerprint patterns that are similar to displaying the percentage recognition of match patterns by matching the input input values with the fingerprint test patterns with the reference images in the training pattern comparing the values of the input representations in the two images. For a long time training is determined by the level of understanding and the number of units.

\section{Conclusion}

In the hidden layer. The system has the fastest training time of 14 seconds with a level of understanding of 0.3 and the number of hidden display units 10 . The more fingerprint image patterns used in the training process, it will make the system more likely to recognize each of the result patterns tested. If the training pattern is 1 piece, the system is able to recognize an external pattern of $50 \%$ while with training pattern 5 , the system is able to recognize an external fingerprint pattern of $70 \%$.

\section{References}

[1] Rina Candra Noor Santi, "Identifikasi Biometrik Sidik Jari dengan Metode Fraktal", Jurnal Teknologi Informasi DINAMIK Volume XIII, No.1, Januari 2008 : 68-72.

[2] Andika D.L. Tumuli et al.,"Implementasi Teknologi Biometrical Identification untuk Login Hotspot “, E-Journal Teknik Informatika Vol.12, No. 1 (2017), ISSN: 23018364. 
[3] Mutia Fadhilla et al,. "Pengenalan Kepribadian Seseorang Berdasarkan Pola Tulisan Tangan Menggunakan Jaringan Saraf Tiruan”, JNTETI, Vol. 6, No. 3, Agustus 2017.

[4] Tambunan Frinto, "Pengenalan Aksara Batak Dengan Metode Perceptron", Jurnal Riset Sistem Informasi Dan Teknik Informatika (JURASIK) Volume (4) Juli 2019, pp 160-170

[5] Aris Budi S et al., "Pengenalan Citra Wajah Sebagai Identifier Menggunakan Metode Principal Component Analysis (PCA)", Jurnal Teknik Informatika Vol 9 No. 2, oktober 2016.

[6] Restu Poetra Alqurni et al,. "Pengenalan Tanda Tangan Menggunakan Metode Jaringan Saraf Tiruan Perceptron Dan Backpropagation", Techno.COM, Vol. 15, No. 4, November $2016: 352-363$.

[7] Eny Maria et al., "Segmentasi Citra Digital Bentuk Daun Pada Tanaman Di Politani Samarinda Menggunakan Metode Thresholding”, JURTI, Vol.2 No.1, Juni 2018, ISSN: 2579-8790.

[8] Jong Jek Siang, "Jaringan Saraf Tiruan \& Pemrogramanya Menggunakan MATLAB", Penerbit Andi, Yogyakarta, 2004.

\section{Authors}

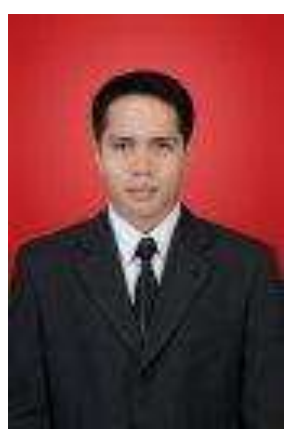

$\mathbf{1}^{\text {st }}$ Author

Frinto Tambunan

Universitas Potensi Utama, Medan, North Sumatra 